\title{
ERRATUM
}

\section{Erratum to: An Update on Implants for Minimally Invasive Glaucoma Surgery (MIGS)}

Ejaz Ansari

Published online: September 13, 2017

(c) The Author(s) 2017. This article is an open access publication

Erratum to: Ophthalmol Ther

DOI 10.1007/s40123-017-0098-2
Few details published in Table 2 were incorrect. The correct Table 2 should read as follows:

The author of this article would like to acknowledge errors in the original publication of this review article.

Table 2 Summary of efficacy and safety data

\begin{tabular}{|c|c|c|c|c|c|}
\hline & $\begin{array}{l}\text { Phaco/ } \\
\text { iStent }[8]\end{array}$ & $\begin{array}{l}\text { Phaco/ } \\
\text { Hydrus [13] }\end{array}$ & $\begin{array}{l}\text { Phaco/ } \\
\text { CyPass [17] }\end{array}$ & $\begin{array}{l}\text { Phaco/ } \\
\text { XEN45 [21] }\end{array}$ & InnFocus [22] \\
\hline Pre-op IOP & 18.6 & 26.3 & 24.4 & 16 & 23.8 \\
\hline Post-op IOP & 17.0 & 16.9 & 17.0 & 12 & 10.7 \\
\hline $\begin{array}{l}\% \text { IOP drop; } \\
\% \\
\text { medication } \\
\text { reduction }\end{array}$ & $\begin{array}{l}33 \% ; 87 \% \\
\quad \text { (versus } \\
32.5 \% ; 73 \% \\
\text { in controls) }\end{array}$ & $\begin{array}{l}\text { 50\%; } 73 \% \\
\text { (versus } 28 \% \text {; } \\
38 \% \text { in } \\
\text { controls) }\end{array}$ & $\begin{array}{l}30.3 \% ; 85.7 \% \\
\text { (versus } 22 \% \text {; } \\
53.9 \% \text { in } \\
\text { controls) }\end{array}$ & $25 \% ; 84.2 \%$ & $55 \% ; 69.2 \%$ \\
\hline AEs & & $\begin{array}{l}12 \% \text { focal } \\
\text { peripheral } \\
\text { anterior } \\
\text { synechiae }\end{array}$ & & $\begin{array}{l}\text { Transcient choroidal } \\
\text { detachment }=2 \text {, tube } \\
\text { extrusion }=1, \\
\text { trabeculectomy }=2\end{array}$ & $\begin{array}{l}\text { Transcient } \\
\text { hypotony }=13 \%, \\
\text { transcient choroidal } \\
\text { effusion }=8.7 \%\end{array}$ \\
\hline
\end{tabular}

The online version of the original article can be found under doi:10.1007/s40123-017-0098-2.

E. Ansari ( $\square)$

Maidstone \& Tunbridge Wells NHS Trust,

Maidstone, UK

e-mail: e.ansari@nhs.net

E. Ansari

University of Kent, Canterbury, UK
Reference 8 was published incorrectly. The correct reference is as follows:

8. Craven R, Katz LF, Wells JM, for the iStent Study Group, et al. Cataract surgery with trabecular micro-bypass stent implantation in patients with mild to moderate open angle glaucoma and cataract: two year follow-up. J Cataract Ref Surg. 2012;38:1339-45. 
Open Access. This article is distributed under the terms of the Creative Commons Attribution-NonCommercial 4.0 International License (http://creativecommons.org/licenses/ by-nc/4.0/), which permits any noncommercial use, distribution, and reproduction in any medium, provided you give appropriate credit to the original author(s) and the source, provide a link to the Creative Commons license, and indicate if changes were made. 